\title{
Incorporating policies for a healthy food system into land use planning: The case of Waterloo Region, Canada
}

\author{
Ellen Desjardins, a, * John Lubczynski, ${ }^{b}$ Marc Xuerebc
}

Submitted 21 April 2011 / Accepted 19 July 2011 / Published online 3 October 2011

Citation: Desjardins, E., Lubczynski, J., \& Xuereb, M. (2011). Incorporating policies for a healthy food system into land use planning: The case of Waterloo Region, Canada. Journal of Agriculture, Food Systems, and Community Development, 2(1), $127-140$. http://dx.doi.org/10.5304/jafscd.2011.021.003

Copyright (C) 2011 by New Leaf Associates, Inc.

\begin{abstract}
Land use planning is a critical tool among the strategies needed to redirect our food system into a new trajectory toward improved health, environmental sustainability, and small to midsize farm viability. We present the case of the region of Waterloo, Ontario, Canada, where recent revisions to the Regional Official Plan (ROP) now include a suite of specific land use policies related to food.
\end{abstract}

${ }^{a}$ Region of Waterloo Public Health (until September 2006), 99 Regina Street South, 3 ${ }^{\text {rd }}$ Floor, Waterloo ON N2J 4V3 Canada

Ellen Desjardins is now at the Department of Geography and Environmental Management, University of Waterloo.

${ }^{\mathrm{b}}$ Region of Waterloo Planning, Housing and Community Services Department, 150 Frederick Street, 8th Floor, Kitchener, ON N2G 4J3 Canada;

¿Lubczynski@regionofwaterloo.ca

${ }^{\mathrm{c}}$ Region of Waterloo Public Health, 99 Regina Street South, 3rd Floor, Waterloo, ON N2J 4V3 Canada; mxuereb@regionofwaterloo.ca

* Corresponding author: Ellen Desjardins, RD PhD, Department of Geography and Environmental Management, University of Waterloo, 200 University Avenue West, Waterloo, ON N2L 3G1 Canada; +1-519-886-0386; desj2665@mylaurier.ca
What characterizes food systems planning in Waterloo is the inclusion of both rural and urban land use policies, and close collaboration between the Planning and Public Health departments. This article documents the context in which this partnership took shape, the process of information gathering and community consultation, and the specific food-related policies that were included in the ROP. The relevance of these policies to the local produce auction, community markets, community gardens, and on-farm stores illustrates how policy emerges from practice, and also suggests that policy work is an ongoing work in progress.

\section{Keywords}

Canada, farm viability, food policy, food system planning, healthy food access, land use planning, local food system, public health, official plan, Waterloo Region

\section{Introduction}

Land use planning is a critical tool among the strategies needed to redirect our food system into a new trajectory toward improved health, environmental sustainability, small to midsize farm viability, and community engagement. Inequality and 
deterioration in these areas have been broadly documented and have led to a growing recognition of the need for policy change, including the consideration of food-related issues when planning our urban communities. This has prompted increased awareness and involvement among professional urban planners in initiatives that aim to systemically revitalize local food chains (Campbell, 2004; Kaufman, 2009; Nichol, 2003; Pothukuchi \& Kaufman, 1999). Changing existing land use policies that support food systems is never simple. It requires knowledge of the existing regulatory structure and is fraught with tensions between commercial and public interests, which are often not clear-cut. This work is therefore politically sensitive in nature and requires cooperation with and input from relevant stakeholders. It also needs evidence and data on which to base planning decisions. Time intensive as this process might be, it can be seen as a valuable opportunity for enhancing understanding of the local food system and building support among citizens, politicians, and rural and urban planners - thus creating a foundation for ongoing systemic change.

We present here the case of the region of Waterloo, Ontario, Canada, where revisions to the Regional Official Plan (ROP) included, for the first time in a Canadian context, a suite of specific landuse policies related to food (Region of Waterloo, 2010a). There are numerous examples of basic support for the production, processing, and retail of locally grown food embedded in official or comprehensive plans throughout Canada and the USA (Canadian Institute of Planners, 2010; Raja, Born, \& Purcell, 2008). For instance, the Toronto Official Plan promotes the creation of community gardens and reducing loss of foodlands to urban sprawl (City of Toronto, 2009, pp. 1-5; Wekerle, 2004). However, planning policies that prescribe rather than just promote such efforts are more rare. They can be enshrined at the "macro level" in provincial or regional government official plans, which then allows local municipalities to implement food-related policies at the "mid- and micro-levels" by passing and enforcing detailed zoning regulations (Oswald, 2009). Examples in Canada of macro-level policies include the new
Manitoba Planning Act, which directs and guides municipalities to designate allowable sizes and locations of livestock operations in their local land use plans (Grift, 2009); and the Ontario Provincial Policy Statement (PPS), which requires local municipalities to establish criteria for farmers wishing to produce value-added farm products from their farm operations (Ontario Ministry of Municipal Affairs and Housing, 2005). An example of a micro-level policy is any local municipal bylaw that would permit a neighborhood market selling locally grown food (Maan Miedema, 2008; Raja et al., 2008, pp. 23-26).

What has uniquely characterized food systems planning in Waterloo is the inclusion of both rural and urban land use policies, and close collaboration between the Planning and Public Health departments. This article documents the context in which this partnership took shape, the process of information gathering and community consultation, and the specific land use policies that were included in the ROP. The relevance of these policies to initiatives such as the local produce auction, community markets, community gardens, and on-farm stores illustrates how policy emerges from practice, but also suggests that policy work is an on-going work in progress.

\section{The Context: A Midsized Rural-Urban Community}

The region of Waterloo is located approximately 62 miles $(100 \mathrm{~km})$ west of Toronto, and is part of a larger economic region in Ontario known as the "Greater Golden Horseshoe." The region consists of three cities, Kitchener, Waterloo, and Cambridge, and four rural townships that contain several smaller towns and villages. With a population of just over half a million people (the tenth largest urban area in Canada), it has a mix of smalltown qualities as well as big city amenities, including two universities and several leading-edge technology companies such as Research in Motion (RIM).

Waterloo Region, situated between the Great Lakes, has always had a vibrant and productive agricultural sector because it has some of the highest quality farmland in Canada. A unique 
contribution to the region's strong rural economy comes from the large concentration of Mennonite and Amish people, whose way of life and farming practices explain the greater number of smaller, mixed farms in the region compared to elsewhere in Ontario.

\section{Concerns About Health and}

Urban/Rural Development

Shortly into the new millennium, the Waterloo Region Planning Department and Public Health Department were both engaged in operational planning that saw their issues converge. Planners were preparing a new Growth Management Strategy and revised Official Plan, while Public Health had established a new Health Determinants division which was striving to improve contextual influences - social, economic and environmental - on health. Basically, the issues of concern were threefold:

\section{Strong Urban Growth, but Health and}

Environmental Issues: Given its location and economy, Waterloo Region is one of the fastest growing urban areas in the country. Over the next 20 years, the population is projected to grow by about $40 \%$, to over 700,000 people. Although growth has positive benefits, it also presents several challenges. Like the majority of North American cities, much residential growth is occurring in suburban areas that are isolated from where people work and shop. Not only does this pattern of growth consume valuable farmland, but it also contributes to increased levels of car use, air pollution, and greenhouse gas emissions. Recent studies have linked these planning issues to health problems such as obesity, diabetes, and asthma (Abelsohn, Bray, Vakil, \& Elliott, 2005).

\section{Agricultural Importance to the Economy, but} Rural Decline: A consultant provided data that showed the significance of the farm sector to the Waterloo Region economy: in 2002 it supported about 3,450 full-time jobs, or $11.3 \%$ of the region's total labor force (Cummings, H. \& Associates Inc., 2003). As well, each agricultural job supports four additional jobs in the local economy, and each dollar of sales in the agricultural sector generates an extra CA $\$ 2.40$ of sales in the local economy. Yet farm incomes and the number of smaller farms in the region were in decline, leading to stress in rural communities due to the resultant reduction in schools, services, and businesses, despite the strong resiliency of residents (Zupko, Shearer, \& Vermeulen, 2004).

\section{Abundance of Rich Farmland, but Inadequate Diet at the Population Level and Insufficient Access to Healthy Food: As early as 2000, Public} Health in Waterloo Region had begun thinking about the food system as a determinant of health, with social, economic, and environmental dimensions (Desjardins \& Xuereb, 2005). For example, in 2003 over half $(58 \%)$ its residents were consuming insufficient servings of fruits and vegetables, and half the population was either overweight or obese (Statistics Canada, 2004). Public Health recognized that the growing incidence of diet- and weightrelated chronic diseases was determined in part by the types of food available to people where they live, work, and study. Unhealthy foods were becoming more convenient and affordable, farmdirect markets were not accessible to everyone, and food retailing had declined in urban core areas. At the same time, farmers had limited opportunities for selling their produce and other local foods, both in the country and the city (Soots, 2003). From a policy perspective, therefore, it made sense to adopt a food system approach in addressing the range of seemingly disconnected food issues. Not only would this approach help improve access to locally grown food and contribute to the dietary health of the population, but it would also improve rural viability and prosperity (Buzby, 2006; CDC, 2009; Hawkes, 2007; Lang, Barling, \& Caraher, 2009; McCullum, 2004). It illustrates the value of transdisciplinary cooperation in beginning to address inequities in various dimensions of the food system (Wallerstein, Yen, \& Syme, 2011).

The need for a more integrated policy approach led to collaborations between Public Health staff and urban planners. Arguing for the potential for improving health, the environment, social equity, and the economy through land use planning policies, Public Health advocated successfully for food 
system planning to be part of the Growth

Management Strategy, which was being led by the Planning Department. The creation of a food system plan for Waterloo Region became one of over 80 projects authorized by Regional Council in 2003 to implement the goals of the Growth Management Strategy.

\section{Community Food System Assessment}

To inform the food system plan, Public Health used two types of methodologies. First, Public Health staff and an external consultant were assigned to prepare a number of background research studies to build a database about various aspects of the Waterloo Region food system (table 1). These reports consisted, for the most part, of primary data gathered from sources in Waterloo Region, as well as analyses of that data to calculate indices such as food miles and indicators of redundant trade. The advisory committee included planning staff, farmers, and food industry representatives, who advised on data collection and helped interpret the data. Second, after data had been compiled and distilled into a set of recommended actions, Public Health held a series of 11 focus groups to determine the priorities and commitments of various stakeholder groups regarding those actions. oatmeal, carrots, tomatoes, and strawberry jam. They picked random samples of these foods in supermarkets and traced them back to their sources. While some of those foods originated from Ontario, the majority were rarely or not sourced from Waterloo Region. The region's food system is heavily invested in global trade: for example, much of its beef goes to processing plants to be made into frozen burger patties for export, while a considerable amount of fresh meat is imported from Alberta and New Zealand (Cummings, H., \& Associates Inc., 2005).

Redundant Trade Study: Public Health staff conducted a series of grocery store and farmers' market audits (including measurement of shelf space) in order to determine the extent to which imported produce was available during the peak season of local produce. The analysis showed it to be considerable. For example, in June, $5 \%$ of instore displays sold region of Waterloo strawberries, while $73 \%$ sold Ontario strawberries and $22 \%$ sold strawberries imported from the U.S. (Maan Miedema, 2005).

Food Miles Study: This environmental impact study looked at a set of 58 commonly consumed foods grown or raised in Waterloo Region, and cal-
Some of the reports in table 1 were presented to regional councilors for their information, and all were published on the region's website. These were good opportunities for bringing diverse aspects of the food system to the attention of councilors, planners, and the public. Highlights of a selection of four of these reports follow.

Food Flow Study: To determine how much of the food consumed in Waterloo Region was grown or raised there, consultants picked a representative basket of 20 commonly consumed foods which are also produced locally, including ground beef, cheddar cheese, quick
Table 1. Food System Reports by Region of Waterloo Public Health*

\begin{tabular}{ll}
\hline Growing Food and Economy Study & 2003 \\
\hline Rural Health Study & 2003 \\
\hline Diet, Weight and Diabetes & 2004 \\
\hline Food Access Study & 2004 \\
\hline Local Food Buying in Waterloo Region & 2004 \\
\hline Optimal Nutrition Environment Study & 2005 \\
\hline Marketing \& Branding of “Buy Local Buy Fresh” & 2005 \\
\hline Urban Agriculture Report & 2005 \\
\hline Food Flow Analysis Study & 2005 \\
\hline Food Miles Study & 2006 \\
\hline Redundant Trade Study & 2006 \\
\hline Towards a Healthy Community Food System in Waterloo Region & 2005 \\
\hline Food System Plan for Waterloo Region & 2007 \\
\hline Neighborhood Markets Evaluation & 2008 \\
\hline
\end{tabular}

* Waterloo Region Public Health Food Reports are available at www.region.waterloo.on.ca/ph (Research Studies/Food). 
culated the number of miles travelled by imports of these same types of foods. On average, these imports travelled almost 2,800 miles $(4,500 \mathrm{~km})$, and together generated over 51,000 tons of greenhouse gas emissions annually (Xuereb, 2005).

\section{Optimal Nutrition Environment Study: This}

study estimated the quantity of locally grown vegetables, fruits, legumes, and whole grains needed to help meet the region of Waterloo population's optimal nutritional requirements in 2006 and as projected in 2026. The study further estimated how much of these healthy food requirements could realistically be produced through local agriculture by the year 2026. Analysis showed that a shift of approximately $10 \%$ of currently cropped hectares to the production of key nutritious food crops would be both agriculturally feasible and nutritionally significant to the population. This study was later published (Desjardins, MacRae, \& Schumilas, 2010), and adapted for the city of Toronto (MacRae et al., 2010).

\section{Discussion Paper: Towards a Healthy Community Food System in Waterloo Region}

In October 2005, Public Health published a report that summarized the findings of the background studies and related literature, and proposed seven strategic objectives to move toward the goal of a healthy food system, one in which "all residents have access to, and can afford to buy safe, nutritious, culturally acceptable food that has been produced in an environmentally sustainable way and that sustains our rural communities" (Desjardins \& Xuereb, 2005, p. 4). Four land use-related objectives were included: to preserve Waterloo Region's farmland, to increase availability of healthy food, to increase the viability of farms, and to strengthen the local food economy (Desjardins \& Xuereb, 2005).

\section{Consultations with Food System Stakeholders}

To test how the proposed food system strategies resonated with the community and to gauge their buy-in toward the goals, in early 2006 Public Health invited stakeholders from different groups - farmers, land use planners, technical advisors (including staff from the Ontario Federation of
Agriculture and the Ontario Ministry of Agriculture and Food), Old Order Mennonite producers, restaurant owners, food retailers, institutional food buyers, and consumers - to participate in 11 focus groups.

Qualitative analysis of the consultation data revealed many specific actions, out of which six were highlighted and presented back to participants in a follow-up forum in June 2006. These actions, plus a seventh one, were consequently accepted as priorities: (1) promote local food, (2) pilot mobile farmers' markets, (3) examine the feasibility of farm-to-institution programs, (4) expand the labeling of local food, (5) address zoning issues for farming, (6) investigate incubator kitchens, and (7) create a new body to oversee the plan. This work was later summarized in the document, $A$ Healthy Community Food System Plan for $W$ aterloo Region (Maan Miedema \& Pigott, 2007).

The consultation process was not only extremely informative, but also served to engage stakeholders in thinking about their role in the food system as a whole. In addition, it gave legitimacy to the goals proposed in the Food System Plan and lent population-based support to the land use policies that were later built into the ROP. Thus, the overall process represented the transformation of local food and agriculture data into a set of clear strategies, with public and professional input as a catalyst. The next step was to turn these strategies into policies and community-centered actions.

\section{Result: Projects and Policies That Support a Healthy Food System}

\section{Waterloo Region Food System Roundtable}

The seventh action mentioned above was a recognition that the identified priority actions were beyond the mandates of Public Health and Planning, and would require a body of people representative of the key interests and sectors of the food system to oversee the new food system plan. Consequently, after a year of organizational planning, the Waterloo Region Food System

Roundtable was inaugurated late in 2007. It consisted of 18 representatives from key sectors 
and interests of the food system (planners, farmers, food manufacturers and distributors, restaurant owners, health professionals, food poverty advocates, researchers, etc.). Financial and staff support was provided through the Public Health Department.

The Roundtable has now assumed the role of overseeing the implementation of the 2007 Food System Plan mentioned above. It seeks to engage the community in discussions, to support food-related policy development, and to facilitate networking among existing food groups and stakeholders. To date, it has achieved these objectives through regular meetings, public forums, letters of support for local projects, and a website designed to enable networking and discussion among people on food issues. A day-long community food summit in 2009 resulted in naming six priorities — food sovereignty, food policy, urban agriculture, local food infrastructure, farm viability, and access to healthy food - as well as a Summit Declaration. ${ }^{1}$ Significantly, the Roundtable was able to provide input into and support for food-related policies in drafts of the ROP, via two letters and presentations to Regional Council.

\section{Food-Related Policies in the $2009 \mathrm{~W}$ aterloo Region Official Plan}

The new ROP, adopted by Regional Council in June 2009, includes an entirely new section, "Access to Locally Grown and Other Healthy Foods" (appendix, figure 1), which was drawn up by planners and reviewed by staff from Public Health. This section includes a preamble that clearly sets out the region's interest in food system planning, explaining what the region is trying to achieve. Significantly, it adds new food-related policies into the sections on general development policies and transit-oriented development. Details on specific ROP food-related policies, and how some of them came into being, are as follows:

\footnotetext{
${ }^{1}$ The Declaration of the Waterloo Region Food Summit (2009) can be accessed at http://www.wrfoodsystem.ca/files/ www/FOOD SUMMIT DECLARATION.pdf
}

Countryside Line: For a strong and sustainable food system, urban sprawl must be contained in order to protect our most valuable farm land. To that end, planners proposed a hard-edge urban growth boundary in the new Official Plan called the "Countryside Line." Unlike traditional urban boundaries in Ontario, the Countryside Line defines the long-term, and in some cases, ultimate, limits of urban growth in the region. Of all the policies, this has been perhaps the most difficult to implement. At first, planners were contemplating a permanent urban growth boundary around the region. Eventually, through the approval process, the Countryside Line became a permanent urban boundary in some locations, and a "long-term" boundary in others. The map in figure 2 (next page) shows the position of the Countryside Line as it was approved by Council in $2009 .^{2}$

Elmira Produce Auction: This is an example of a private-sector initiative that required some new ways of thinking for the land use planners who reviewed its application. In 2003, a group of Old Order Mennonite farmers asked for a rural building permit to establish a produce auction where farmers could sell wholesale quantities of their produce cooperatively. The internal rules of the auction's operators permitted only growers within a 47 mile $(75 \mathrm{~km})$ radius of the town of Elmira to sell their products at the auction. This limit was intended to support local farm incomes by encouraging diversification into higher value crops such as seasonal fruit and produce. Sellers range from hobby gardeners to large produce operations. Some farmers use the auction to offload surplus crops, while others see it as a reliable sales outlet for their products. Public Health and Planning staff were excited by the prospect of establishing one of the missing links in the local food system: a one-stop place for urban retailers to access locally grown food.

The establishment of this commercially related land use, however, normally would not have been permitted in an agricultural zone under a strict

\footnotetext{
${ }^{2}$ As of the writing of this article, this and other sections of the ROP are under appeal by various parties to the Ontario Municipal Board. A decision is not expected until at least 2012.
} 


\section{Figure 2. The Countryside Line, Waterloo Region Official Plan}

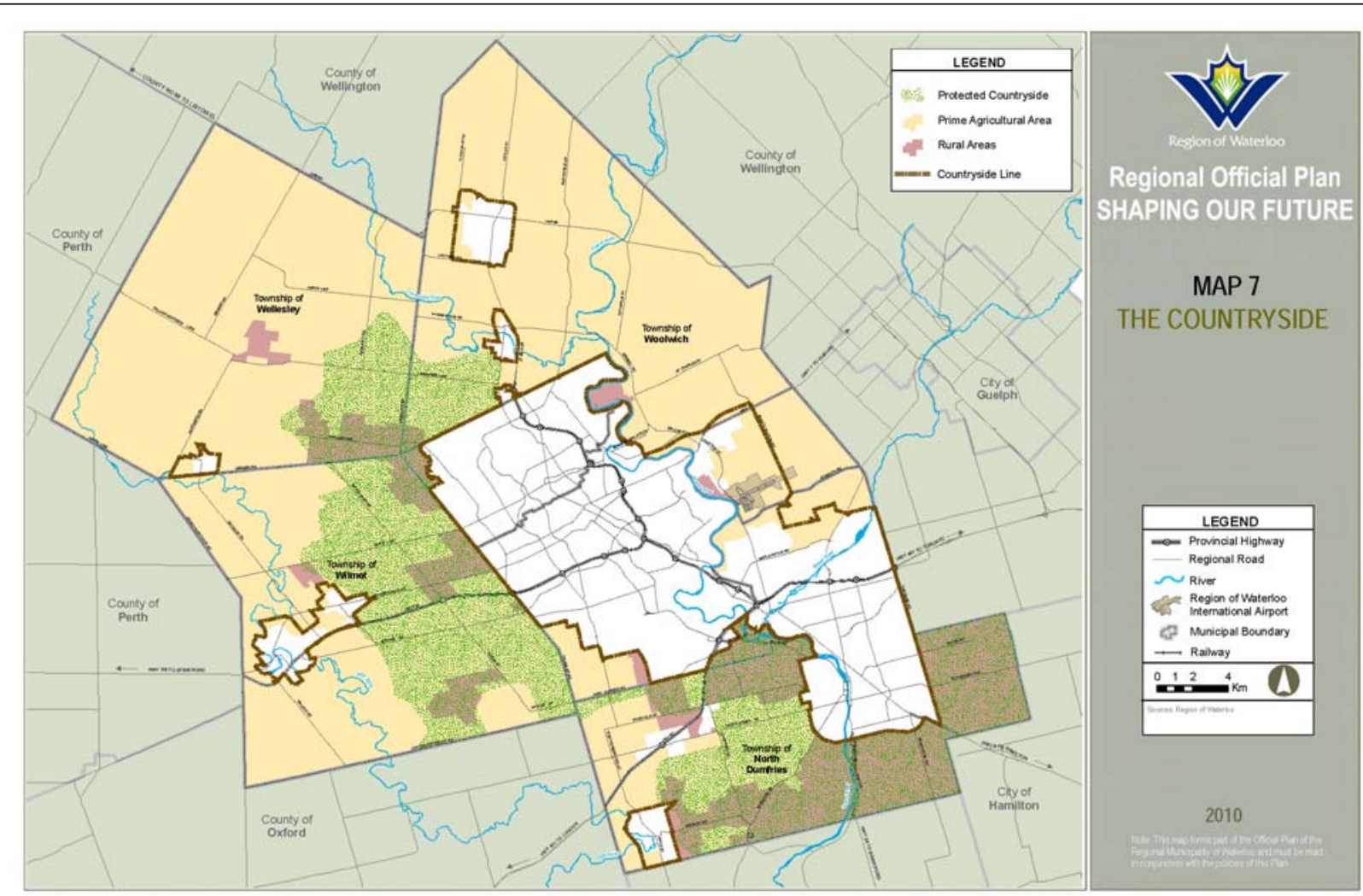

Urban areas are white; yellow and green areas represent the countryside. The thick brown line surrounding the white areas is the Countryside Line. The green area surrounding the southern and western side of the three cities is designated as the Protected Countryside. Where the Countryside Line abuts the Protected Countryside, the Countryside Line is to be considered a permanent growth boundary. In all other areas, the Countryside Line is considered a long-term urban boundary.

interpretation of the township's ${ }^{3}$ zoning bylaw. Nevertheless, after consulting with Regional staff about the many benefits of the auction to local farmers and the food system, the township eventually supported it through a zoning bylaw amendment. Initially, the auction was approved as a temporary "agriculture-related use" that could be renewed every three years, but it was soon made permanent. Produce auctions have since been added as a permitted agriculture-related use under the region of Waterloo's new Official Plan.

Better Support for On-Farm Business: Regarding farm viability, one of the key messages Public

\footnotetext{
${ }^{3}$ Elmira is in Woolwich Township, one of Waterloo Region's seven area municipalities.
}

Health heard from farmers in the 2006 public consultations was that simply saving farmland was not enough to keep them on the land; they also needed to be allowed to diversify their on-farm income.

Planners reviewed existing agricultural policies, but were concerned that relaxing the goal of keeping the countryside dedicated to farming might open the door to the proliferation of inappropriate commercial uses across the countryside. Therefore, they drafted new policy in a way that supports onfarm business, but at the same ensures that it remains small-scale and secondary to, but compatible with, surrounding farm operations.

An example of allowing such on-farm business was a beef farm in the township of North Dumfries. Thirteen years earlier, when the mad cow disease 
crisis hit Canada, the family decided to sell its herd as freezer beef, starting with one freezer in the garage. Unexpectedly, the popularity of their products grew, leading them to network with neighboring farmers to diversify their line of local food products. Their business grew to the point where it became viable to build a store on their farm to serve as a retail hub for neighboring farms. Ultimately the family received approval from the township to construct a small store to sell food from neighboring farms, including fresh produce, dairy products, and home baked items, in addition to their own grass-fed Black Angus beef. They added an in-store kitchen to generate value-added food products from the farm, and now employ several workers. In 2009, their efforts were recognized with a Premier's Award for Agri-Food Innovation Excellence. From a land use policy perspective, the township was able to support the retail/commercial aspect of this farm operation because the store was small in scale, secondary to the farm operation and helped support the local farm community. Establishing such criteria in municipal planning documents can help remove the zoning barriers farmers face in starting on-farm businesses.

Neighborhood Markets: In 2007, Public Health received a grant for a two-year pilot program to establish neighborhood produce markets in areas with limited food availability. The markets aimed to increase access to healthy food and at the same time support local farmers (Maan Miedema, 2009). They faced a challenge, as municipal zoning bylaws did not permit such market operations in the locations where Public Health proposed to put them, and licensing fees were prohibitively expensive considering their small scale. However, the local municipal planners saw that the Regional government was promoting the idea as part of its councilapproved Food System Plan, which led them to permit the markets because they were a "public service." One of the first neighborhood markets, in the hospital parking lot at St. Mary's Hospital in Kitchener, won a Health Promotion Innovation award from the Ontario Ministry of Health and Long-Term Care for its produce market. The region subsequently added a new policy to its ROP, approved in 2009, that requires area municipalities to establish policies that permit temporary farmers' markets "wherever appropriate." It defined temporary farmers' markets as "outdoor food stands using temporary structures to sell food products to the public...primarily from local sources" (Region of Waterloo, 2010, p. G-19). Three of these neighborhood markets, now independently operated, continue to this day. One neighborhood market, operated by community organizations in the City of Cambridge, was the first to receive permission to operate without the intervention of the region after the implementation of the new ROP provisions.

Urban Agriculture: The region's Public Health Department has been supporting a network of over 40 community gardens in the region for several years (Mazereeuw, 2005). The number has continued to grow, but some gardens have faced obstacles such as acquiring land and resources to start and maintain them - issues within the purview of municipalities. The ROP incorporated policies to enable community gardens by granting access to region-owned lands, and by providing forms of in-kind support such as rain barrels, composting bins, compost, and wood mulch. With this official support, at least one new community garden has been approved on region-owned lands.

\section{Discussion}

In retrospect, it is clear that the process of incorporating food-related policies — both rural and urban - into the Waterloo ROP has emphasized the roles of collaboration and thorough research in order to build the requisite political will. To date, the ROP was approved by the province of Ontario, but still faces appeals from some parties. Such inherent complexity may be a reason why, in general, community-engaged food system planning that aims to improve population health and small to midsize farm viability has been slow in coming, in addition to the reasons noted by Pothukuchi and Kaufman (2004) and Clancy (2004). In a survey of planners in Ontario that served as the basis for the recent food-related document $A$ Call to Action (Ontario Professional Planners Institute, 2011), only $15 \%$ of Ontario planners reported significant 
involvement in food issues, but $61 \%$ said they would like be more involved. Setting the stage, the case of developing food policy in Waterloo Region has highlighted the merit of a synergistic partnership between Public Health, Planning, and food system stakeholders to build a rationale and process for change.

Time will tell whether these policies will have the desired effects and in what ways they will influence actions in both urban and rural areas. This points to the importance of monitoring the social, economic, agricultural, and developmental outcomes and challenges that result from implementing food policies in the ROP. A key component to monitor is change to the food environment, for which precise indicators are required. Wegener has noted the significance of assessing the "alternative" food retail environment, such as farm stores, famers' markets, and mobile produce stands, suggesting that "zoning designations to enable the establishment and expansion of these outlets could make an important contribution to improving the availability and accessibility of health-promoting foods" (2009, p. 47). Research by Minaker, Fisher, and Raine (in press) intends to develop standard measures of the food environment that are shown to be associated with diet and health, and that will be useable and feasible to implement by municipalities, urban planners, and developers. These activities accentuate the value of a research partner in the on-going pursuit of effective policy development, a role for which interested university programs are ideally suited.

Overall, the current Waterloo ROP should be seen as a starting point. There will be unforeseen outcomes due to shifting social circumstances, new information, and the uncertain nature of political processes. This overall reality makes the issues and opportunities unique to every region, leading to parallel — but different — land use policy developments that are currently in progress in other jurisdictions throughout North America. In Ontario, there is a need for a coordinated policy framework, within the Provincial Policy Statement, for land use planning that promotes access to healthy food for consumers as well as food-related enterprises that can improve regional farm viability and sustain farm land. To make this happen, it will be essential to share information regularly among planners and other stakeholders across different regions, and to collectively identify common strategic threads and standards that work. Thanks to greater participation of planners in creating food-based land use policies, the healthy food system snowball has started to roll.

\section{References}

Abelsohn, A., Bray, R., Vakil, C., \& Elliott, D. (2005). Report on public health and urban sprawl in Ontario: $A$ review of the pertinent literature. Environmental Health Committee, Ontario College of Family Physicians. Retrieved from http://www.ocfp.on.ca/docs/ public-policy-documents/urbansprawl.pdf

Buzby, J. D., Wells, H. F., \& Vocke, G. (2006). Possible implications for U.S. agriculture from adoption of select dietary guidelines. Economic Research Service, USDA. Economic Research Report No. 31. Retrieved from http://www.ers.usda.gov/ publications/err31

Campbell, M. C. (2004). Building a common table: The role of planning in community food systems. Journal of Planning Education and Research, 23(4), 341-355. http://dx.doi.org/10.1177/0739456X04264916

Centers for Disease Control and Prevention (CDC). (2009). State indicator report on fruits and vegetables 2009. Retrieved from http://www. fruitsandveggies matter.gov/downloads/StateIndicator Report2009.pdf

City of Toronto. (2009). Toronto Official Plan. Retrieved from http://www.toronto.ca/planning/ official plan/introduction.htm

Clancy, K. (2004). Potential contributions of planning to community food systems. Journal of Planning Education and Research, 23(4), 435-438. http://dx.doi.org/10.1177/0739456X04264893

Cummings, H., \& Associates Inc. (2003). Growing food and economy: Economic impact study of the agriculture and food-related sectors in Waterloo Region. Region of Waterloo Public Health. Retrived from http://chd.region.waterloo.on.ca/en/research ResourcesPublications/resources/FoodEconomy_ $\underline{\text { Study.pdf }}$ 
Cummings, H., \& Associates Inc. (2005). Region of Waterloo food flow analysis study. Region of Waterloo Public Health. http://chd.region.waterloo.on.ca/ en/researchResourcesPublications/resources/ FoodFlow Analysis.pdf

Desjardins, E., MacRae, R., \& Schumilas, T. (2010). Linking future population food requirements for health with local production in Waterloo Region, Canada. Agriculture and Human V alues, 27(2), 129-140. http://dx.doi.org/10.1007/s10460-0099204-y

Desjardins, E., \& Xuereb, M. (2005). Towards a bealthy community food system for Waterloo Region. Region of Waterloo Public Health. Retrieved from http://chd.region.waterloo.on.ca/en/research ResourcesPublications/resources/FoodSystems Report.pdf

Grift, S. (2009). Planning for sustainable livestock and agricultural development in Manitoba. Plan Canada, 49(2), 21-23.

Hawkes, C. (2007). Promoting healthy diets and tackling obesity and diet-related chronic diseases: What are the agricultural policy levers? Food and Nutrition Bulletin, 28(2), S312-S322.

Kaufman, J. L. (2009). Food system planning: Moving up the planner's ladder. Plan Canada, 49(2), 12-16.

Lang, T., Barling, D., \& Caraher, M. (2009). Food policy: Integrating health, environment and society. Oxford, UK: Oxford University Press.

Maan Miedema, J. (2009). Neighbourhood markets: Outcome evaluation. Region of Waterloo Public Health. Retrieved from http://chd.region.waterloo.on.ca/ en/researchResourcesPublications/resources/ NM Evaluation.pdf

Maan Miedema, J. (2006). A study of redundant trade in Waterloo Region. Region of Waterloo Public Health. Retrieved from http://chd.region.waterloo.on.ca/ en/researchResourcesPublications/resources/ Redundant Trade.pdf

Maan Miedema, J., \& Pigott, K. (2007). A bealthy community food system plan for $W$ aterloo Region. Region of Waterloo Public Health. Retrieved from http://chd.region.waterloo.on.ca/en/researchReso urcesPublications/resources/FoodSystem Plan.pdf

MacRae, R., Gallanta, E., Patel, S., Michalak, M., Bunch, M., \& Schaffner, S. (2010). Could Toronto provide $10 \%$ of its fresh vegetable requirements from within its own boundaries? Matching consumption requirements with growing spaces. Journal of Agriculture, Food Systems and Community Development, 1(2), 105-127. http://dx.doi.org/10.5304/jafscd. $\underline{2010.012 .008}$

Mazereeuw, B. (2005). Urban agriculture report. Region of Waterloo Public Health. Retrieved from http://chd.region.waterloo.on.ca/en/ researchResourcesPublications/resources/ UrbanAgriculture.pdf

McCullum, C. (2004). Using sustainable agriculture to improve human nutrition and health. Journal of Community Nutrition, 6(1), 18-25.

Mendes, W. (2007). Negotiating a place for "sustainability" policies in municipal planning and governance: The role of scalar discourses and practices. Space \& Polity, 11(1), 95-119.

Minaker, L. M., Fisher P., \& Raine, K. D. (In press). Measuring food retail access: From theory to planning practice. Journal of Agriculture, Food Systems and Community Development. http://www.AgDevJournal.com

Nichol, L. (2003). Local food production: Some implications for planning. Planning Theory \& Practice, 4(4), 409-427. http://dx.doi.org/10.1080/ 1464935032000146264

Ontario Ministry of Municipal Affairs and Housing. (2005). Ontario Provincial Policy Statement. Retrieved from http://www.mah.gov.on.ca/Page215.aspx

Ontario Professional Planners Institute. (2011). Healthy communities and planning for food: Planning for food systems in Ontario: $A$ call to action. Retrieved from http://www.ontarioplanners.on.ca/ $\% 5 \mathrm{Cpdf} \% 5 \mathrm{Ca}$ call to action from oppi june 24 2011.pdf

Oswald, J. (2009). Planning for urban agriculture. Plan Canada (Canadian Institute of Planners), 49(2), 35-38.

Pothukuchi, K., \& Kaufman, J. L. (1999). Placing the food system on the urban agenda: The role of municipal institutions in food systems planning. Agriculture and Human Values, 16(2), 213-224. http://dx.doi.org/10.1023/A:1007558805953

Raja, S., Born, B., \& Russell, J. K. (2008). A planner's guide to community and regional food planning: Transforming food environments, facilitating bealthy eating. Chicago, Illinois: American Planning Association.

Region of Waterloo. (2010). Regional Official Plan Documents [Glossary]. Retrieved from http://www.regionofwaterloo.ca/en/regional Government/PreviousROP.asp 
Soots, L. K. (2003). Home Grown: Local Food System Development in Waterloo Region. (Unpublished master's thesis). University of Waterloo, Department of Environment and Resource Studies, Waterloo, Ontario.

Statistics Canada (2004). Canadian Community Health Survey, Cycle 1.1, 2000/01. Retrieved from http://www.statcan.gc.ca/concepts/healthsante/index-eng.htm

Wallerstein, N. B., Yen, I. R., \& Syme, L. S. (2011). Integration of social epidemiology and communityengaged interventions to improve health equity. American Journal of Public Health. 101(5), 822-830. http://dx.doi.org/10.2105/AJPH.2008.140988

Wegener, J. (2009). "Alternative" food outlets and their relevance to policy and planning decisions. Plan Canada (Canadian Institute of Planners), 49(2), 46-48.
Wekerle, G. R. (2004). Food justice movements: Policy, planning, and networks. Journal of Planning Education and Research, 23(4), 378-386. http://dx.doi.org/ 10.1177/0739456X04264886

Xuereb, M. (2005). Food miles: Environmental implications of food imports to Waterloo Region. Region of Waterloo Public Health. Retrieved from http://chd.region.waterloo.on.ca/en/research ResourcesPublications/resources/FoodMiles Report.pdf

Zupko, B., Shearer, J., \& Vermeulen, K. (2004). Rural bealth study in Waterloo Region: Final report 2004. Region of Waterloo Public Health. Retrieved from http://chd.region.waterloo.on.ca/en/ researchResourcesPublications/resources/ RuralHealth Study.pdf 


\title{
Appendix.
}

\section{Figure 1. Excerpts from Waterloo Region Official Plan}

\author{
http://www.region.waterloo.on.ca/newrop
}

\section{Chapter 3. Liveability in Waterloo Region}

\section{F Access to Locally Grown and Other Healthy Foods}

The regional food system consists of the chain of activities related to the production, processing, distribution, consumption and eventual disposal of food. A strong and diverse regional food system provides many benefits to the community. It facilitates peoples' access to locally grown and other healthy foods, which contributes to healthier eating choices and the achievement of broader public health objectives. It also encourages a range of food destinations within easy walking distance of where people live and work. Such a system helps shorten the distance that food travels and that people travel to buy food, thereby reducing the demand on transportation infrastructure and the growth in vehicle emissions. As well, a strong regional food system supports local farmers and contributes to the vitality and economic strength of rural communities and Waterloo Region as a whole. For these reasons, this Plan seeks to strengthen and diversify the regional food system.

3.F.1 The Region will support the development of a strong regional food system through the policies in this Plan that:

(a) establish a Countryside Line to protect the countryside for long-term agricultural use;

(b) permit a full range of agricultural uses, farm-related uses and secondary uses to support the economic viability of local farms;

(c) provide for a mix of land uses, including food destinations, within close proximity of each other to facilitate residents' access to locally grown and other healthy food products; and

(d) provide a range of human services including affordable housing, subsidized daycare, employment and income supports that seek to ensure all residents have adequate incomes to be able to afford to buy locally grown and other healthy food products.

3.F.2 Area Municipalities will establish policies in their official plans to permit temporary farmers' markets, wherever appropriate, in existing and newly planned neighborhoods, particularly in areas where access to locally grown food and other healthy food products may currently be limited.

3.F.3 Area Municipalities will establish policies in their official plans that encourage community gardens and rooftop gardens.

3.F.4 The Region will support community gardens, wherever feasible, by granting access to Regional lands, and by providing rain barrels, composting bins, compost, wood mulch or other forms of inkind support.

3.F.5 The Region will collaborate with stakeholders to continue to implement initiatives supporting the development of a strong regional food system.

3.F.6 The Region supports food system planning as a means of improving the regional food system. 


\section{Chapter 2. Shaping Waterloo Region's Urban Communities}

\section{General Development Policies}

2.D.1 In preparing or reviewing planning studies, or in reviewing development applications or site plans, the Region and/or Area Municipalities will ensure that development occurring within the Urban Area is planned and developed in a manner that:

...

(g) facilitates residents' access to locally grown and other healthy foods in neighborhoods;

\section{Transit Oriented Development Policies}

2.D.2 In addition to the general development provisions described in Policy 2.D.1, the Region and Area Municipalities will apply the following Transit Oriented Development provisions in reviewing development applications or site plans, on or near sites that are served by existing or planned rapid transit, or higher frequency transit to ensure that development:

...

(c) provides an appropriate mix of land uses, including a range of food destinations, that allows people to walk or take transit to work, and also provides for a variety of services and amenities that foster vibrant, transit-supportive neighborhoods;

\section{Urban Designated Greenfield Areas}

2.D.17 Area Municipalities, in collaboration with the Region, will ensure that development occurring in Urban Designated Greenfield Areas will be planned and developed to:

(c) establish a network of continuous sidewalks, community trails and bicycle pathways that provide direct, safe, comfortable and convenient linkages within the neighborhood and externally to other neighborhoods, including linkages to transit stops, employment areas, school sites, food destinations and community facilities. 
Journal of Agriculture, Food Systems, and Community Development ISSN: 2152-0801 online www.AgDevJournal.com 